\title{
Intestinal absorption of calcium from yogurt in lactase-deficient subjects
}

\author{
A Wynckel 1, F Jaisser 1, T Wong 1, T Drüeke 2, J Chanard 1* \\ 1 Service de Néphrologie, Centre Hospitalier et Universitaire, 45, rue Cognacq-Jay, 51100 Reims; \\ 2 INSERM U90, Hôpital Necker, 161, rue de Sèvres, 75015 Paris, France
}

(Received 12 December 1990; accepted 25 March 1991)

\begin{abstract}
Summary - Fractional intestinal absorption of calcium (FACa) was measured using radioactive calcium and $200 \mathrm{mg}$ of calcium carrier provided either by yogurt or by $\mathrm{CaCl}_{2}$ in 7 lactase-deficient $(\mathrm{L}(-))$ and 7 normal $(L(+))$ subjects. During the control period prior to yogurt consumption, mean calcium intake was $819 \mathrm{mg}$ per day in $\mathrm{L}(-)$ and $931 \mathrm{mg}$ per day in $\mathrm{L}(+)$ subjects (NS). In both groups of subjects yogurt increased FACa from $20.8 \pm 3.9 \%$ to $26.9 \pm 7.2 \%(P=0.065)$ in $L(+)$ subjects and from $20.2 \pm 5.6 \%$ to $23.5 \pm 6.4 \%(P=0.050)$ in $L(-)$ subjects. The significarit increase in FACa observed in $L(-)$ subjects indicates that yogurt, which is an autodigesting source of lactose, does not impair calcium absorption. FACa increase could reflect the lower dietary calcium intake in $L(-)$ subjects when compared with $\mathrm{L}(+)$ subjects, due to avoidance of milk and non-fermented dairy products which could cause intestinal discomfort. It is concluded that yogurt is a well-tolerated and efficient source of calcium in subjects with lactase deficiency.
\end{abstract}

calcium absorption / lactase-deficiency / yogurt

Résumé - Absorption intestinale du calcium chez les sujets déficients en lactose consommant du yaourt. L'absorption fractionnelle du calcium (FACa) a été mesurée en utilisant du calcium radioactif administré avec $200 \mathrm{mg}$ de salcium comme entraîneur, apporté soit sous forme de yaourt soit sous forme de $\mathrm{CaCl}_{2}$ chez 7 sujets déficients en lactase $(L(-))$ et chez 7 sujets sans déficit lactasique $(L(+))$. Pendant la période contrôle, avant l'ingestion de yaourt, la consommation moyenne de calcium était de $819 \mathrm{mg}$ par jour chez les sujets $L(-)$ et de $931 \mathrm{mg}$ par jour chez les sujets $L(+)$ (NS). Dans les deux groupes de sujets, l'ingestion de yaourt a augmenté $F A C a$ : de $20,8 \pm 3,9 \%$ à 26,9 \pm $7,2 \%(P=0,065)$ chez les sujets $L(+)$ et de $20,2 \pm 5,6 \%$ à $23,5 \pm 6,4 \%(P=0,050)$ chez les sujets $L$ $(-)$. L'augmentation significative de FACa observée chez les sujets $L(-)$ indique que le yaourt, qui induit l'hydrolyse du lactose, n'altère pas l'absorption intestinale du calcium. L'augmentation de FACa observée chez les sujets $L(-)$ pourrait être en rapport avec de moindres apports calciques alimentaires que ceux mesurés chez les sujets $L(+)$, cette différence étant imputable à la non ingestion de lait et de produit laitiers non fermentés qui induisent des troubles dyspeptiques. En conclusion, le yaourt permet un apport diététique de calcium d'origine lactée chez les sujet déficient en lactase intestinale.

abscrption intestinale du calcium / déficit en lactase / yaourt

\footnotetext{
* Correspondence and reprints
} 


\section{INTRODUCTION}

Intestinal calcium absorption has been shown to depend in part on the presence of carbohydrates in the gut lumen. In animal experiments lactose, as well as some other sugars, has been shown to increase calcium absorption (Wasserman and Taylor, 1969; Fournier et al, 1972). In man, several studies have addressed this issue but the results obtained are conflicting and difficult to compare because of varying methodologies (Greenwald et al, 1963; Birge et al, 1967; Pansu and Chapuy, 1970; Condon et al, 1970; Kocian et al, 1973; Cochet et al, 1983; Smith et al, 1985; Griessen et al, 1989). Lactose may have a stimulatory effect on calcium absorption. However, this effect is obviously dependent upon the activity of the intestinal enzyme lactase which hydrolyses lactose to glucose and galactose.

A great number of Caucasian adults are lactase-deficient (Simoons, 1969), and such a defect has been documented in many patients with osteoporosis (Newcomer et al, 1978). Lactose maldigestion and malabsorption in lactase-deficiency may lead to calcium deficiency, especially in aged subjects, since intestinal calcium absorption has been shown to decrease with age (Avioli et al, 1965; Bullamore et al, 1970; Ireland and Fortran, 1973; Gallagher et al, 1979). In addition, aged subjects reportedly consume lower amounts of unmodified milk than younger subjects. In order to avoid a diet deficient in calcium and to preserve the stimulatory effect of lactose in the process of intestinal calcium absorption, yogurt or cultured milk may be ingested in large quantities. In individuals with lactase deficiency, the hydrolysis of lactose achieved by the lactase ( $\beta$ galactosidase) of microorganisms used for yogurt processing is particularly beneficial (Tamine and Deeth, 1980). Therefore, milk provided as yogurt may lead to an improved digestion and absorption of lactose as well as of calcium.

Using a simplified method for the measurement of fractional intestinal absorption of calcium (FACa) (Chanard et al, 1974), we have investigated the effect of yogurt on the intestinal absorption of calcium in subjects with normal lactose tolerance and in patients with lactose intolerance in order to explore a possible beneficial effect of this dairy product on calcium availability.

\section{SUBJECT AND METHOD}

\section{Subjects}

Fourteen volunteers participated in the study. They received a complete explanation of the study and gave informed consent. The study was accepted by the ethical committee of our institution. Subjects were divided into 2 groups: group I comprised 7 healthy normal lactase volunteers $(L(+))$ aged 23-58 yr and group II comprised 7 lactase-deficient subjects $(L(-))$ aged 23-74 yr. All were in good health and taking no drugs. Physical examination was normal. Serum calcium, phosphorus, total protein, alkaline phosphatases, creatinine, uric acid and glucose were within normal limits as were serum 25 (OH) cholecalciferol, immunoreactive 63-84 PTH and osteocalcin. Lactose intolerance was detected by a $100 \mathrm{~g}$ lactose-tolerance test (Welsh, 1970 ) and confirmed by breath analysis according to Calloway et al (1969).

\section{Study protocol}

All subjects were ambulatory and maintained for the control period on their usual diet. Nutritional status was carefully investigated by expert dieticians throughout the study period. At the end of the 4-wk control period, FACa was measured. Thereafter, yogurt was introduced into the diet which remained otherwise unmodified. $125 \mathrm{~g}$ of commercial unflavoured yogurt (Danone BSN, 
France) containing $\approx 6.5 \mathrm{~g}$ lactose and $150 \mathrm{mg}$ calcium was taken 3 times a day at the end of each meal. Yogurt was consumed $3 d$ of preparation. After $\mathbf{8}$ d of yogurt supplementation, $\mathrm{FACa}$ was again measured.

\section{Measurements}

Fractional intestinal absorption of calcium was measured as previously described (Chanard et al, 1974, 1976) using ${ }^{45} \mathrm{Ca}$ successively administered intravenously $(4 \mu \mathrm{Ci}=148 \mathrm{kBq})$ and then orally $(7-8 \mu \mathrm{Ci}=245-300 \mathrm{k} \mathrm{Bq}) 2 \mathrm{~h}$ later. The test was performed on subjects who had been fasting for $12 \mathrm{~h}$. The oral dose was given together with $200 \mathrm{mg}$ of elemental calcium as $\mathrm{CaCl}_{2}$ in $100 \mathrm{ml}$ water during the first test and with 150 $\mathrm{mg}$ calcium provided by yogurt mixed with 50 mg calcium as $\mathrm{CaCl}_{2}$ during the second test. FACa was measured 2, 4 and $6 \mathrm{~h}$ after the oral dose. As an equilibrium of radiocalcium absorbed and radiocalcium remaining in the gut is normally reached within 2-4 $\mathrm{h}$ after the oral dose (Birge et al, 1969), FACa values have been quoted as the mean of all determinations.

The nutritonal status of the subjects was defined by dietary recall, according to tables which have been established to take into account the characteristics of French dietary habits (Souci et al, 1981; Feinberg et al, 1991).

Radioactive calcium was measured in a liquid scintillation spectrometer (LS 230 Beckmann Instrument). All counts were corrected for quenching. Blood chemistry was performed according to automatic methods and radioimmunoassays using commercial tests (Oris, Saclay, France).

\section{Statistical analysis}

Results were expressed as mean $\pm S D$. Data were analyzed as part of a 2-treatment $(Y(-)$ and $Y(+))$ open study in which differences between treatment groups and between periods were examined. Differences between $L(+)$ and $L(-)$ groups at baseline were assessed with use of the Wilcoxon rank-sum test for continuous data. Changes from baseline after yogurt ingestion were assessed with Student's paired $t$-test.
All tests were 2-tailed and an alpha of 0.05 indicated significance.

\section{RESULTS}

Table I indicates the mean values of estimated diet components and energy intake as evaluated during the 2 study periods. When yogurt was introduced, nutritional habits changed slightly. An increase in the consumption of calcium and phosphorus was therefore observed. The mean increase in calcium intake was $166 \mathrm{mg}$ per day $(17.8 \%)$ in $L(+)$ and $194 \mathrm{mg}$ per day $(23.7 \%)$ in $L(-)$ subjects respectively.

Fractional absorption of calcium did not differ significantly at 2, 4 and $6 \mathrm{~h}$ after the oral dose of ${ }^{45} \mathrm{Ca}$ in each of the 4 subgroups defined as $L(+)$ and $L(-)$ subjects, taking $(Y(+))$ or not taking $(Y(-))$ yogurt (table II). In the absence of yogurt, FACa was similar in $L(+)$ and $L(-)$ subjects $(20.8$ $\pm 3.9 \%$ vs $20.2 \pm 5.6 \%(P=N S))$. The administration of yogurt induced an increase in FACa both in $\mathrm{L}(+)$ and in $\mathrm{L}(-)$ subjects: $26.9 \pm 7.2 \%$ and $23.5 \pm 6.4 \%$ respectively. In $L(-)$ subjects this increase was significant whereas in $L(+)$ subjects it was not (fig 1).

\section{DISCUSSION}

An improvement in intestinal calcium absorption both in healthy subjects with normal lactase activity and in those with lactase deficiency, when a test dose of radiocalcium given together with yogurt compared with radiocalcium given together with calcium chloride in water has been documented.

In $L(-)$ and $L(+)$ subjects, mean FACa was increased after yogurt consumption. This increase was significant in $L(-)$ sub- 


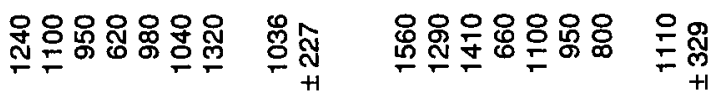

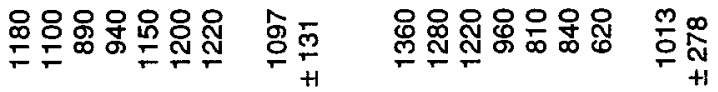

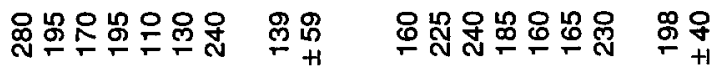

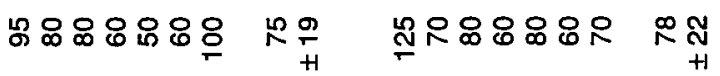

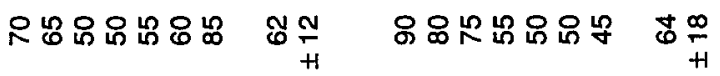

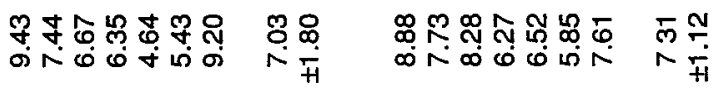

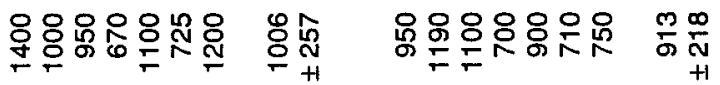

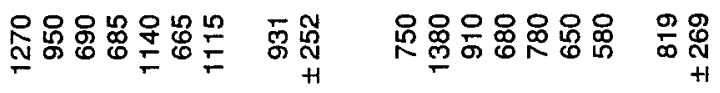

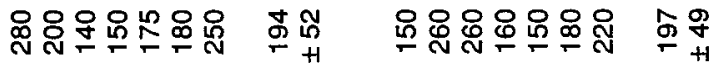

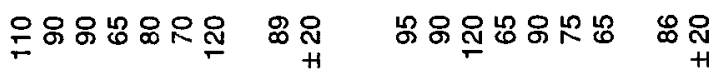

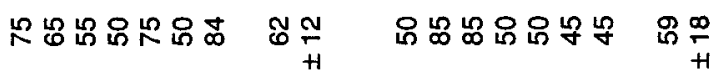

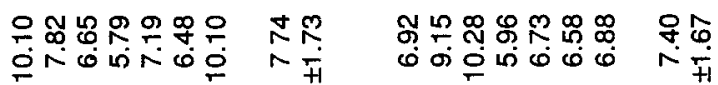

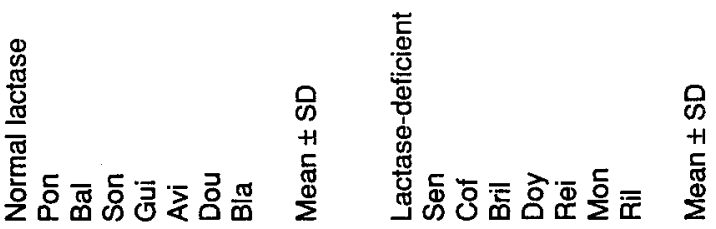


Table II. Fractional intestinal absorption of calcium measured 2,4 and $6 \mathrm{~h}$ after the oral administration of radiocalcium with $(\mathrm{Y}(+))$ or without $(\mathrm{Y}(-))$ yogurt as carrier, in normal lactase and lactase-deficient subjects.

\begin{tabular}{|c|c|c|c|c|c|c|c|c|c|c|}
\hline \multirow[t]{2}{*}{ Subject } & \multirow[t]{2}{*}{ Age } & \multirow[t]{2}{*}{ Sex } & \multicolumn{4}{|c|}{ Without yogurt } & \multicolumn{4}{|c|}{ With yogurt } \\
\hline & & & $2 h$ & $4 h$ & $6 h$ & $m$ & $2 h$ & $4 h$ & $6 h$ & $m$ \\
\hline \multicolumn{11}{|c|}{ Normal lactase } \\
\hline Pon & 23 & $M$ & 19.3 & 30.2 & 23.1 & 24.2 & 36.0 & 42.0 & 33.1 & 37.0 \\
\hline Bal & 27 & $M$ & 24.4 & 31.1 & 31.1 & 26.1 & 30.0 & 42.0 & 32.0 & 32.0 \\
\hline Son & 23 & $\mathrm{~F}$ & 27.0 & 20.0 & 17.0 & 21.3 & 19.1 & 21.0 & 15.9 & 18.7 \\
\hline Gui & 25 & $\mathrm{~F}$ & 18.9 & 23.1 & 22.7 & 21.6 & 30.0 & 36.0 & 31.0 & 32.3 \\
\hline Avi & 22 & $\mathrm{~F}$ & 16.8 & 13.0 & 14.7 & 14.8 & 21.5 & 28.0 & 22.5 & 24.0 \\
\hline Dou & 24 & $F$ & 13.4 & 15.1 & 21.8 & 16.8 & 17.1 & 20.2 & 17.9 & 18.3 \\
\hline Bla & 58 & $F$ & 20.1 & 22.0 & 21.0 & 21.0 & 25.0 & 27.0 & 25.0 & 26.0 \\
\hline Mean \pm SD & & & $\begin{array}{r}20.0 \\
\pm 4.5\end{array}$ & $\begin{array}{r}22.1 \\
\pm 6.9\end{array}$ & $\begin{array}{r}20.9 \\
\pm 3.9\end{array}$ & $\begin{array}{r}20.8 \\
\pm 3.9\end{array}$ & $\begin{array}{r}25.5 \\
\pm 6.8\end{array}$ & $\begin{array}{r}29.7 \\
\pm 8.0\end{array}$ & $\begin{array}{r}25.3 \\
\pm 6.9\end{array}$ & $\begin{array}{r}26.9 \\
\pm 7.2\end{array}$ \\
\hline \multicolumn{11}{|c|}{ Lactase-deficient } \\
\hline Sen & 25 & $\mathrm{~F}$ & 25.6 & 33.6 & 30.7 & 30.0 & 38.8 & 28.2 & 33.0 & 33.3 \\
\hline Gof & 23 & $M$ & 18.1 & 23.9 & 23.1 & 21.7 & 25.2 & 28.8 & 26.2 & 26.7 \\
\hline $\mathrm{Bri}$ & 24 & $M$ & 22.3 & 19.3 & 26.5 & 22.7 & 33.0 & 29.0 & 27.0 & 29.7 \\
\hline Doy & 62 & $M$ & 18.5 & 20.0 & 18.5 & 19.0 & 19.0 & 20.1 & 21.0 & 20.0 \\
\hline Rei & 69 & M & 20.0 & 21.0 & 19.0 & 20.0 & 18.0 & 18.5 & 18.5 & 18.0 \\
\hline Mon & 72 & $F$ & 14.7 & 19.2 & 14.2 & 16.1 & 15.4 & 18.1 & 17.6 & 17.0 \\
\hline Ril & 74 & $F$ & 13.0 & 12.0 & 10.9 & 12.0 & 20.2 & 20.0 & 19.1 & 19.8 \\
\hline Mean \pm SD & & & $\begin{array}{r}18.9 \\
\pm 4.3\end{array}$ & $\begin{array}{r}21.3 \\
\pm 6.5\end{array}$ & $\begin{array}{r}20.4 \\
\pm 6.9\end{array}$ & $\begin{array}{r}20.2 \\
\pm 5.6\end{array}$ & $\begin{array}{r}24.2 \\
\pm 8.7\end{array}$ & $\begin{array}{r}23.1 \\
\pm 5.3\end{array}$ & $\begin{array}{r}23.2 \\
\pm 5.7\end{array}$ & $\begin{array}{c}23.5^{*} \\
\pm 6.4\end{array}$ \\
\hline
\end{tabular}

* Indicates significant changes between $Y(-)$ and $Y(+)$.

jects but not in $L(+)$ subjects. The discrepancy between $L(-)$ and $L(+)$ subjects may be explained by the small size and the age heterogeneity of the groups.

The increase in calcium absorption may be the result of several enhancing nutrients contained in yogurt (Pointillart et al, 1986) including casein (Mykkänen and Wassermann, 1980) and lactose (Wasserman and Taylor, 1969). In man, previous studies of calcium absorption in lactasedeficiency have yielded conflicting results, the presence of lactose increasing (Pansu and Chapuy, 1970), decreasing (Condon et al, 1970; Kocian et al, 1973; Debongnie et al, 1979) or having no particular effect (Tremaine et al, 1986) on calcium absorption. In agreement with our findings, Cochet et al (1983) in their extensive study on such subjects found that an oral load of 50 $\mathrm{g}$ of lactose significantly increased FACa by $37 \%$ in the $L(+)$ subjects. However, in $L$ $(-)$ subjects they observed a decrease of $18 \%$ in total calcium absorption. Similarly, 


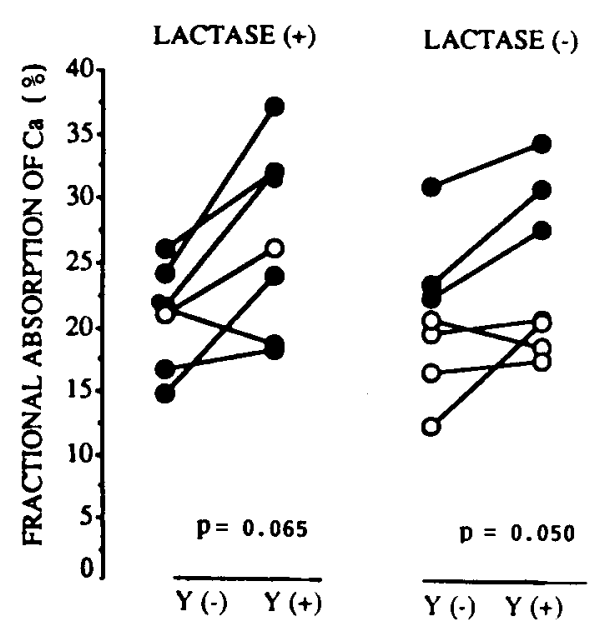

Fig 1. Mean values of $F A C a$ measured after oral administration of radiocalcium given either with yogurt $(Y(+))$ or with $\mathrm{CaCl}_{2}$ in water $(Y(-))$ as carrier, in normal lactase (lactase $(+))$ and lactase-deficient (lactase $(-)$ ) subjects. Closed circles indicate "young" subjects and open ,circles "old" (see text).

Kocian et al (1973) reported that $39 \mathrm{~g}$ lactose had a detrimental effect on calcium absorption in L(-) subjects. Condon et al (1970) have shown that the daily ingestion of $60 \mathrm{~g}$ of lactose decreased fecal and urinary calcium excretion and induced a positive calcium balance but their study was limited to $L(+)$ subjects. Many of these discrepancies may be explained by differences in methodology and especially by different amounts of lactose administered together with the test dose of calcium in order to measure calcium absorption. In our study, where yogurt was used $3 \mathrm{~d}$ after manufacture, an average of $6.5 \mathrm{~g}$ lactose was mixed with radioactive calcium to measure FACa. Other differences in methodology such as $\mathrm{pH}$ and temperature may also play a part, since lactose hydrolysis produced by Lactobacillus bulgaricus and
Streptococcus thermophilus is inhibited at $\mathrm{pH}<4.6$ and at storage temperature. The beneficial role of the enzymatic activity of microorganisms contained in yogurt has been clearly shown by Kolars et al (1984), who demonstrated enhanced lactose absorption in $L(-)$ subjects after the ingestion of yogurt.

A possible effect of age on FACa cannot be asserted in the present study, since only $1 \mathrm{~L}(+)$ subject and $4 \mathrm{~L}(-)$ subjects were $>50$ yr. Irrespective of intestinal lactase activity, mean FACa measured before yogurt consumption was $17.6 \%$ and $22.1 \%$ in old and young subjects, respectively. This difference confirms the hypothesis that FACa decreases with age (Avioli et al, 1965; Bullamore et al, 1970; Ireland and Fortran, 1973), independently of diet and hormonal imbalance. Since osteoporosis is a major health problem in the aging population, reflecting calcium deficiency, adequate intestinal absorption of calcium throughout the entire life probably is a key factor. Insufficient dietary intake of calcium clearly contributes to diminished bone mass (Birge et al, 1969; Newcomer et al, 1978; Gallagher et al, 1979; Cauley et al, 1988). In addition, dietary calcium supplementation has been shown to decrease fracture rate in postmenopausal osteoporosis, even though this finding still remains controversial (Riggs et al, 1982; Holbrook et al, 1988). Intestinal lactase deficiency appears to be frequent in osteoporotic patients and 2 factors could contribute to their negative calcium balance (Scrimshaw and Murray, 1988). The first is calcium deficiency due to avoidance of dairy products because of gastrointestinal disturbances associated with the osmotic effect of nonhydrolyzed lactose. The second is impaired calcium absorption from lactosecontaining foods because the facilitating effect of lactose on lumen to-blood calcium transfer is suppressed. 
In our relatively small group of $L(-)$ subjects, the modest amount of lactose administered with yogurt did not lead to a decrease in FACa. In keeping with this, Smith et al (1985) have demonstrated that the quantity of lactose physiologically present in dairy products, either as milk or as yogurt, does not impair calcium absorption in L(-) subjects. Similar results have been obtained by Griessen et al (1989), at least in lactase-deficient subjects drinking milk without intestinal discomfort.

\section{CONCLUSION}

To conclude, yogurt which is an autodigesting source of lactose, does not impair calcium absorption in L(-) subjects. Moreover, yogurt has an enhancing effect on FACa which was only found to be significant in $L(-)$ subjects. When compared to $L(+)$ subjects, this discrepancy may be due to a lower dietary intake of milk and calcium in $L(-)$ subjects as documented by dietary recall. However we cannot exclude a direct effect of yogurt linked to the amount of hydrolyzed lactose. This latter hypothesis has been challenged by Recker et al (1988) who has indicated in postmenopausal women of unknown lactasic activity, that calcium absorbability from milk, yogurt, cheese and calcium carbonate was not significantly different. Nevertheless, in L(-) subjects yogurt may be a substitute for non-fermented dairy products, allowing an adequate calcium diet without intestinal discomfort.

\section{ACKNOWLEDGMENTS}

We thank Mrs Lizaga for her technical help in evaluating the patients' diets Mrs Falala and Miss C Sene for their expert secretarial assistance. This study was supported by a grant from the European Economic Community (contract No 282/84-82-8).

\section{REFERENCES}

Avioli LV, McDonald JE, Lee SW (1965) The influence of age on the intestinal absorption of ${ }^{47} \mathrm{Ca}$ in women and its relation to ${ }^{47} \mathrm{Ca}$ absorption in post-menopausal osteoporosis. $J$ Clin Invest 44, 1960-1967

Birge SJ Jr, Keutmann HT, Cuatrecasas P, Wheaton GD (1967) Osteoporosis, intestinal lactase-deficiency and low dietary calcium intake. N Engl J Med 276, 445-448

Birge SJ, Peck WA, Berman M, Whedon GD (1969) Study of calcium absorption in man: a kinetic analysis and physiologic model. $J$ Clin Invest 48, 1705-1713

Bullamore JR, Wilkinson R, Callagher JC, Nordin BEC, Marshall DH (1970) Effects of age on calcium absorption. Lancet ii, 535-537

Calloway DH, Murphy EL, Bauer D (1969) Determination of lactose intolerance by breath analysis. Am J Dig Dis 14, 811-815

Cauley JA, Gutai JP, Kuller LH, Le Donne D, Sandler RB, Sashin D, Powell JG (1988) Endogenous estrogen levels and calcium intakes in postmenopausal women. Relationships with cortical bone measures. J Am Med Assoc 260, 3150-3155

Chanard J, Assailly J, Bader C, Funck-Brentano JL. (1974) A rapid method for measurement of fractional intestinal absorption of calcium. J Nucl Med 15, 588-592

Chanard J, Drüeke T, Zingraff J, Man NK, Russo-Marie F, Funck-Brentano JL (1976) Effects of haemodialysis on fractional intestinal absorption of calcium in uraemia. Eur J Clin Invest 6, 261-269

Cochet B, Jung A, Griessen M, Barthold P, Schaller P, Donath A (1983) Effects of lactose on intestinal calcium absorption in nor$\mathrm{mal}$ and lactase-deficient subjects. Gastroenterology 84, 935-940

Condon JR, Nassim JR, Millard FJC, Hilbe A, Stainthorpe EM (1970) Calcium and phosphorus in relation to lactose intolerance. Lancet $\mathrm{i}, 1027-1929$

Debongnie JC, Newcomer AD, Mc Gill DB, Phillips SF (1979) Absorption on nutrients in lactase deficiency. Dig Dis Sci 24, 225-231

Feinberg M, Favier JC, Ireland-Ripert J (1991) Répertoire Général des Aliments. Tables de Composition. INRA, Paris 
Fournier P, Dupuis Y, Fournier A, Diguad A (1972) Contribution à l'étude du mode d'action des os sur l'absorption et la rétention du calcium. CR Acad Sci Paris Sér D 85-89

Gallagher JC, Riggs BL, Eisman J, Hamstra A, Arnaud SB, De Luca HF (1979) Intestinal calcium absorption and serum vitamin $D$ metabolites in normal subjects and osteoporotic patients. Effect of age and dietary calcium. $J$ Clin Invest 64, 729-736

Greenwald E, Samachson J, Spencer H (1963) Effect of lactose on calcium absorption in man. J Nutr 79, 531-538

Griessen $M$, Cochet $B$, Infante $F$, Jung A, Bartholdi $P$, Donath A, Loizeau E, Courvoisier B (1989) Calcium absorption from milk in lactase-deficient subjects. Am J Clin Nutr 49, 377-384

Heaney RP, Recker RR, Saville PD (1978) Menopausal changes in calcium balance performance. J Lab Clin Med 92, 953-963

Holbrook TL, Barrett-Connor E, Wingard DL (1988) Dietary calcium and risk of hip fracture: 14-year prospective population study. Lancet i, 1046-1049

Ireland P, Fortran JS (1973) Effect of dietary calcium and age on jejunal calcium absorption in human studied by intestinal perfusion. $J$ Clin Invest 52, 2672-2681

Kocian J, Skala I, Bakos K (1973) Calcium absorption from milk and lactose free milk in healthy subjects and patients with lactose intolerance. Digestion 9, 317-324

Kolars JC, Levitt MD, Aouji MDAG, Savaino DA (1984) Yogurt. An autodigesting source of lactose. N Engl J Med 310, 1-3

Mykkänen HM, Wassermann RH (1980) Enhanced absorption of calcium by casein phosphopeptides in rachitic and normal chicks. J Nutr 110, 2141-2148

Newcomer AD, Hodgson SF, Mc Gill DB, Thomas PJ (1978) Lactase deficiency prevalence in osteoporosis. Ann Intern Med 89, 218-220

Pansu D, Chapuy MD (1970) Calcium absorption enhanced by lactose and xylose. Calcif Tissue Res 4 (suppl), 155-156
Pointillart A, Cayron B, Guéguen L (1986) Utilisation du calcium et du phosphore et minéralisation osseuse chez le porc consommant du yaourt. Sci Aliment 6, 15-30

Recker RR, Bammi A, Barger-Lux MJ, Heaney RP (1988) Calcium absorbability from milk products, an imitation milk, and calcium carbonate. Am J Clin Nutr 47, 93-95

Riggs BL, Seeman E, Hodgson SF, Taves DR, O'Fallon WM (1982) Effect of the fluoride/ calcium regimen on vertebral fracture occurrence in post-menopausal osteoporosis. N Engl J Med 306, 446-450

Scrimshaw NS, Murray EB (1988) The acceptability of milk and milk products in populations with a high prevalence of lactose intolerance. Am J Clin Nutr 48 (suppl), 1083-1159

Simoons FJ (1969) Primary adult lactose intolerance and the milking habit: a problem in biological and cultural interrelation. I. Review of the medical research. Am J Dig Dis 14, 819836

Smith TM, Kolars JC, Savaiano DA, Levitt MD (1985) Absorption of calcium from milk and yogurt. Am J Clin Nutr 42, 1197-1200

Souci SW, Fackmann W, Kraut H (1981) La Composition des Aliments. Tableaux des Valeurs Nutritives. Wissenschaftliche Verlagsgesellschaft $\mathrm{mbH}$, Stuttgart

Tamine AY, Deeth HC (1980) Yogurt: technology and biochemistry. J Food Prot 43, 939977

Tremaine WJ, Newcomer AD, Riggs BL, McGill DB (1986) Calcium absorption from milk in lactase-deficient and lactase-sufficient adults. Dig Dis Sci 31, 376-378

Wassermann RH, Taylor AN (1969) Some aspects of the intestinal absorption of calcium with special reference to vitamin D. In: Mineral Metabolism III (Comar CL, Bronner F, eds) Academic Press, NY, 321-403

Welsh JD (1970) Isolated lactase deficiency in humans: report on 100 patients. Medicine 48, 257-277 